Int. J. Morphol.,

31(3):915-920, 2013

\title{
Anatomical Basis of the Myofascial Trigger Points of the Trapezius Muscle
}

\author{
Bases Anatómicas de los Puntos de Gatillo Miofasciales del Músculo Trapecio
}

Flávia Emi Akamatsu; Samir Saleh; Henrique Trombini Pinesi; Katarina Reichmann Rodrigues; Cintia Benedicto Zandoná; Mauro Andrade \& Alfredo Luiz Jacomo

AKAMATSU, F. E.; SALEH, S.; PINESI, H. T.; RODRIGUES, K. R.; ZANDONÁ, C. B.; ANDRADE, M. \& JACOMO, A. L. Anatomical basis of the myofascial trigger points of the trapezius muscle. Int. J. Morphol., 31(3):915-920, 2013.

SUMMARY: This study aimed to bring the trapezius muscle, knowledge of the locations where the accessory nerve branches enter the muscle belly to reach the motor endplates and find myofascial trigger points (MTPs). Although anatomoclinical correlations represent a major feature of MTP, no previous reports describing the distribution of the accessory nerve branches and their anatomical relationship with MTP are found in the literature. Both trapezius muscles from twelve adult cadavers were carefully dissected by the authors (anatomy professors and medical graduate students) to observe the exact point where the branches of the spinal accessory nerve entered the muscle belly. Dissection was performed through stratigraphic layers to preserve the motor innervation of the trapezius muscle, which is located deep in the muscle. Eight points were identified: In all cases, these locations corresponded to clinically described MTPs. The eight points where common in these twelve cadavers. This type of clinical correlation between spinal accessory nerve branching and MPT is useful to achieve a better understanding of the anatomical correlation of MTP and the physiopathology of these disorders and may provide a scientific basis for their treatment, providing useful additional information to therapists to achieve better diagnoses and improve therapeutic approaches.

KEY WORDS: Trigger points; Trapezius muscle; Anatomy; Nerves; Myofascial.

\section{INTRODUCTION}

Myofascial pain syndrome (MPS) is the most frequent cause of chronic musculoskeletal pain (Chen et al., 2008; Ge et al., 2008; Hong, 2000; Huguenin, 2004; Simons et al., 2005; White \& Harth, 2001) with estimates of world-wide prevalence ranging from $0.5 \%$ to $5.0 \%$ (Harden et al., 2000; Gran, 2003; White \& Harth). MPS is defined as a focal hyperirritability in muscle tissue (Ferández-de-las-Peñas et al., 2010). This syndrome presents clinically as referred pain (Ge et al., 2009), a limited range of motion in joints (Harden et al.) and a local twitch response following mechanical stimulation of certain muscular and fascial areas, known as myofascial trigger points (MTP) (Simons et al., 2005), and is associated with motor endplates (Chu, 1995). The chronic pain diagnostic taxonomy published by the International Association for the Study of Pain provides no specific criteria for the diagnosis of MPS; rather, it offers a note that the "diagnosis depends upon the demonstration of a trigger point (tender point) and reproduction of pain by maneuvers which place stress upon proximal structures or nerve roots (Merskey \& Bogduk, 1994). The lack of a formal, widely accepted, criterion-based diagnostic scheme has proved to be a serious impediment to proper diagnosis, clinical communication and research related to this topic (Simons et al., 1999).

Four different MTP related to motor innervation have been clinically described for the trapezius muscle (Simons et al., 1999), but data showing anatomical correlations are still lacking (Fumal \& Schoenen, 2008; Sciotti et al., 2001). The complex physiopathology of MTPs is not yet fully understood, but it is theoretically based on the presence and activity of MTP (Hong; Huguenin).

MTP are clinically identified by palpation of a knot or a taut band of muscle or fascia that elicits local tenderness and referred pain (Hong; Lavelle et al., 2007; 
Simons et al., 2002; Simons et al., 2005). Electrophysiological analyses have been published suggesting that an MTP occurs when a nociceptor and a muscular motor endplate coincide (Chu; Karakurum et al., 2001; Simons, 2001; Simons et al., 2002; Tollison et al., 2002). Nevertheless, the lack of anatomical information about these structures constitutes a major obstacle to obtaining a complete understanding of the physiopathology and widespread clinical treatment of MTP.

\section{MATERIAL AND METHOD}

Twelve human adult cadavers ( 6 male and 6 female) were dissected to expose the accessory nerve, with its spinal fibers, wich innervate the trapezius muscle. The cadavers were previously prepared using a $4 \%$ phenolic acid and $0.5 \%$ formaldehyde solution. The cadavers were obtained from a body donation program undertaken by the Discipline of Human Structural Topography of the Department of Surgery of the University of São Paulo Medical School, and this study was approved by the Ethics Committee on Research of the University of São Paulo Medical School under protocol 130/11. Specimens without signs of previous surgery or other severe abnormalities in regions of interest were accepted. The specimens were positioned in ventral decubitus on the dissection table, and a long incision down the spine was made starting from the external occipital protuberance and continuing to the T12 level. Next, flaps of skin and subcutaneous tissue were pulled away laterally to expose the trapezius muscles from both sides. We cut through the attachment of the trapezius to the spines of the vertebrae and then folded the muscle laterally, without damaging the underlying neurovasculature. The spinal accessory nerve arises in the neck through the jugular foramen, descends along the cervical region under the sternocleidomastoid muscle and reflects to the posterior triangle of the neck in the distal third of that muscle, reaching the shoulder where it extends its first branch to the trapezius muscle, which we designated MTP1. This denomination is also employed in clinical settings and corresponds to the anatomical location described in the specimens dissected in this study. Photographic documentation was obtained from these nervous structures. Dissections to identify the exact point where fibers from the spinal accessory nerve enter the trapezius muscle were extremely difficult because of the intricate relationship among the nerve fibers, fascia and fat (Fig. 1). The dissections usually required 3 to 4 periods of 4 hours of careful work under magnifying lenses to thoroughly study the specimens.

\section{RESULTS}

We observed in all of the cadavers that the nerve fibers reached the muscle and tendon in areas coincident with the clinical locations of MTPs described by Simons (Chu; Simons; Simons et al., 2002; Simons et al., 2005).

All four MTPs located in the muscle belly in all cadavers and both insertional MTPs were identified as entry points of the spinal accessory nerve into the trapezius muscle and tendon. The locations of the entry points coincided with the clinical area of MTPs. Variation was observed in two MTPs: point 3 presented two nervous entry points, designated MTP 3 and MTP 3.1, and point 5 presented three different patterns, designated MTP5, MTP5.1 and MTP5.2. MTP1 was situated in the intermediate part of the anterior margin of the upper part of the muscle, as described previously (Figs. 1 and 2). MTP2 was located distal and slightly lateral to the previous MTP (Figs. 1 and 2). MTP3 corresponded to entry points on the margin of medial fibers near the inferior margin of the muscle, and two nerve branches were found in this region in all specimens (Figs. 1 and 2).

Table I. Anatomical location of the MTPs in 12 cadavers (insertional MTPs were not listed).

\begin{tabular}{|c|c|}
\hline Trigger Point & Specimens $1,2,3,4,5,6,7,8,9,10,11$ and $12 /$ Left and Right Side \\
\hline MTP1 & $\begin{array}{l}\text { Intermediate part of the anterior margin of the upper part of the muscle near the vertical fibers } \\
\text { of the muscle attached to clavicle. }\end{array}$ \\
\hline MTP2 & Distal and slightly lateral to the MTP1. \\
\hline MTP3 & Medial to the scapula and on the margin of medial fibers near the inferior margin of the muscle \\
\hline MTP3.1 & $\begin{array}{l}\text { Medial fibers near the inferior margin of the muscle, medial to MTP3; nervous branch always } \\
\text { smaller than MTP3 branch. }\end{array}$ \\
\hline MTP5 & Medial to the scapula in the intermediate part of the muscle belly. \\
\hline MTP5.1 & Medial to the scapula in the intermediate part of the muscle belly inferior to MT5. \\
\hline MTP5.2 & Medial to the scapula in the intermediate part of the muscle belly inferior to MTP5.1. \\
\hline
\end{tabular}


Similarly, MTP5, located in the intermediate part of the muscle belly, presented three different nerve entries (Figs. 1 and 2). The insertional MTP 4 and 6 corresponded to the muscle insertions in the spine of the scapula and acromion (Fig. 2).This was a constant pattern observed in our dissection for all cadavers (Table I).

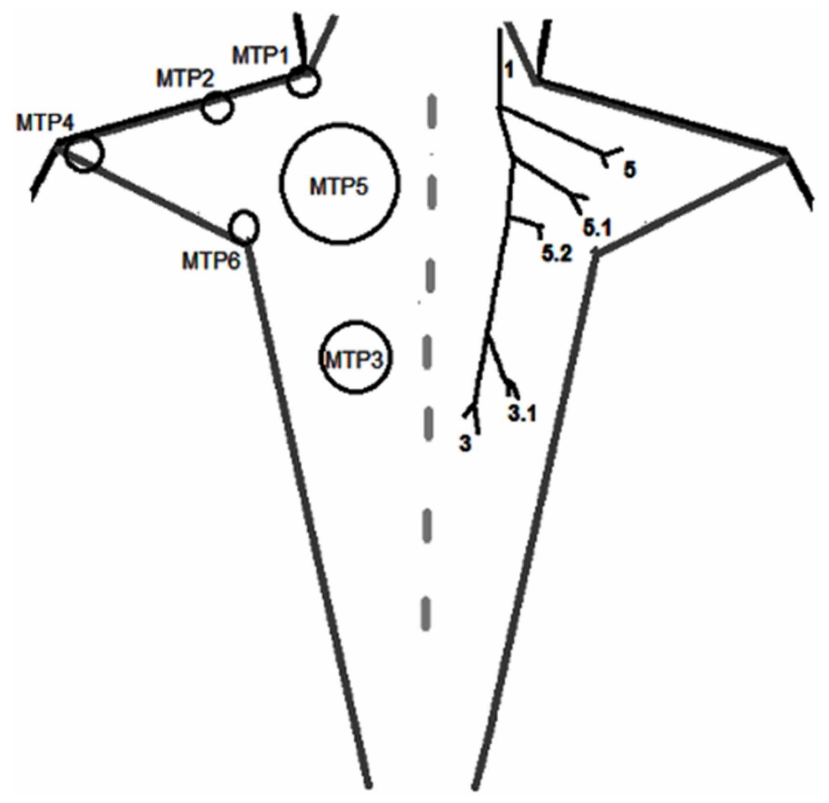

Fig. 1. Scheme of anatomical location of MTP1, MTP2, MTP3, MTP3.1, MTP4, MTP5, MTP5.1, MTP5.2 and MTP6. Motor endplates correspond to MTP1, MTP2, MTP3, MTP3.1, MTP5, MTP5.1, and MTP5.2. MTP 4 and MTP6 are insertional trigger points. Observe on the left side that point 5 and 3 are regions that correspond to nerve insertional points.

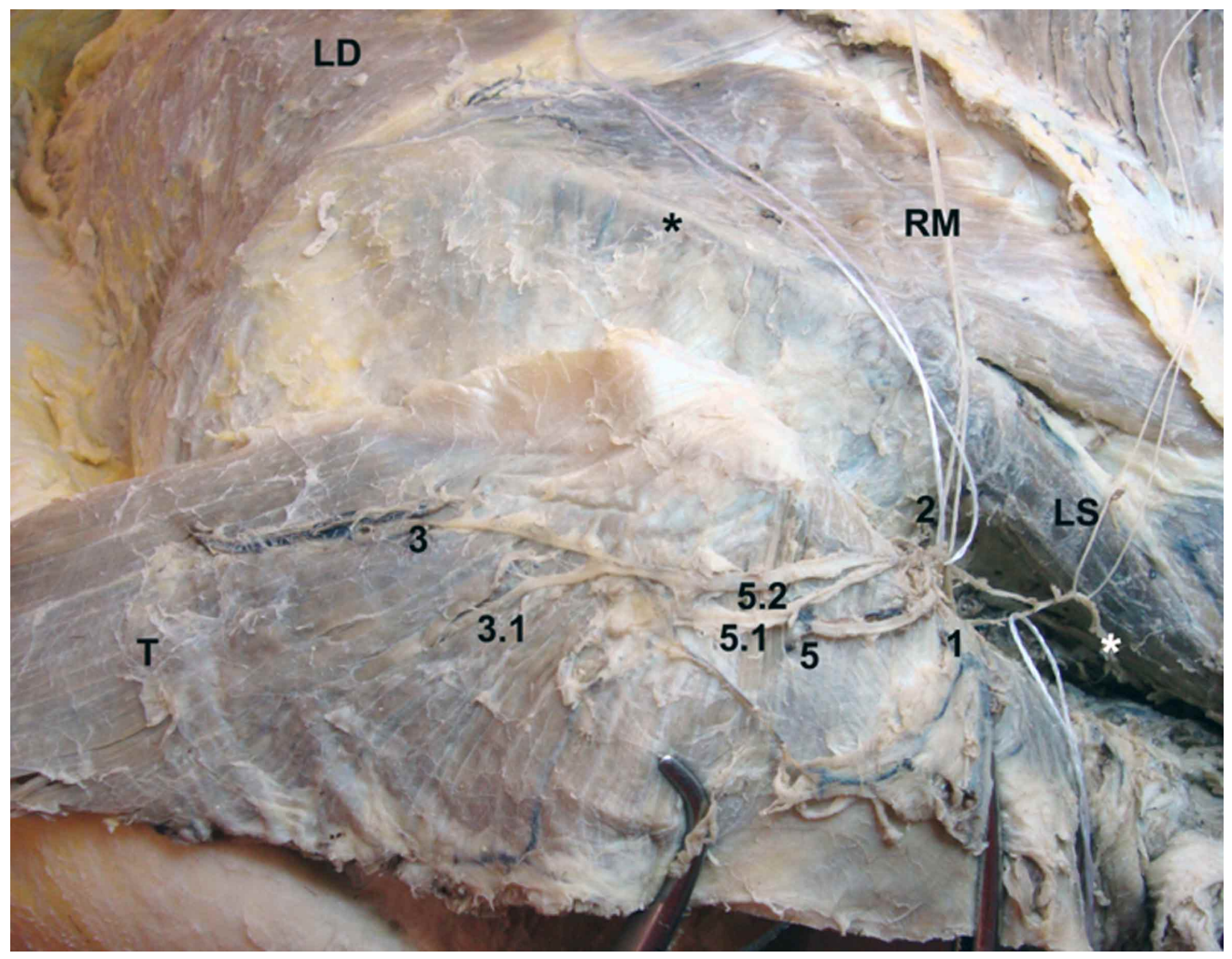

Fig. 2. Gross anatomy image. Dissection of the trapezius muscle and the areas corresponding to the clinical trigger points. Reflection of the right trapezius muscle showing the entry points of the spinal accessory nerve branches that coincide with the MTPs 1, 2, 3, 3.1, 5, 5.1 and 5.2. T= Trapezius muscle; LS= Levator Scapulae; LS= Latissimus Dorsi; RM= Rhomboid Major; *black= medial margin of the scapula $=$; white $=$ Acessory nerve. 


\section{DISCUSSION}

Myofascial trigger points are considered to represent a pathogenic model of pain from diverse etiologies (Hong \& Hsueh, 1996). MTPs, or muscle knots, are a type of electrically active, hyperirritable areas of muscle associated with contractile nodules and dysfunctional motor endplates, known as MTPcentral (MTPC) (Simons et al., 2005). Theoretically, a sensitive spot may be found anywhere in the skeletal muscle but is usually found near the motor endplates (Basmajian \& De Luca, 1985; Hong \& Hsueh; Lavelle et al.; Simons et al., 2002; Simons et al., 2005). MTP can be either active, causing painful disorders, or latent, causing pain only when stimulated (Ge et al., 2008, 2009; Simons et al., 2005). Clinical identification is the most commonly used technique to locate MTP, and both needle and surface electromyography have been described for research purposes (Huguenin; Lavelle et al.; Sciotti et al.). Knowledge of the anatomical location of these structures is essential not only to provide a correct diagnosis but also because many therapeutic modalities include a direct approach of the affected area (Chen et al.; Fernández-delas-Peñas et al.; Hong; Hsueh et al., 1997; Lavelle et al.; Merskey \& Bogduk; Olavi et al., 1989; Simons et al., 2005; Stranding, 2008). Some painful cervical and thoracic disorders are related to trigger points in the trapezius muscle, and misdiagnosis of these conditions is common when the putative responsible MTP are not adequately evaluated (White \& Harth).

The trapezius muscle covers the posterior aspect of the neck and the superior part of the thorax and attaches the upper limb to the skull and vertebrae. Its fibers are divided according to their orientation into superior, intermediate and inferior fibers, each of which exhibits a different action. The superior fibers have their origin in the superior nuchal line and external occipital protuberance and reach the lateral portion of the clavicle. The intermediate fibers retract the scapula and originate from the spinous processes from the 7th cervical to the 3 rd thoracic vertebra and insert on the acromion. These fibers represent the strongest portion of the muscle. The last portion, represented by the inferior fibers, depresses the scapula and lowers the shoulder. Its fibers have their origin in most thoracic spinous processes and insert along the spine of the scapula (Moore \& Dalley, 2010; Stranding). MTP are related to the trapezius muscle (Stranding). Four points are located in the muscle belly of the trapezius: (1) the mid-portion of the superior margin, extending into the vertical fibers that reach the clavicle; (2) caudal and lateral to the first point, in the transverse fibers of the muscle; (3) the medial fibers near the inferior margin of the muscle; and (4) the central part of the muscle belly between the C7-T3 levels. Two additional MTP are found on the tendinous insertion: (1) over the medial part of the spine on the scapula; and (2) on the acromial insertion of the trapezius muscle. There is another MTP superficially located on the posterior aspect of the middle part of the clavicle.

According to Simons et al. (2005), and we found the same, MTP1 of the trapezius muscle is found over the medial anterior margin of the muscle in its superior portion and concerns the most vertical fibers attached to the clavicle. MTP2 is caudal and slightly lateral to MTP1. MTP3 and 5 were easier to identify in our cadavers; MTP3 was located near the inferior margin of the muscle in its inferior fibers of the muscle, showing two insertional points (Figs.1 and 2); and MTP5, as expected from its clinical pattern, was found in several different areas, but with three insertional points (Figs. 1 and 2) rather than only one insertional point as observed clinically, all belonging to the intermediate portion of the muscle. Despite the variations observed in points 3 and 5, it is possible that the clinical localization of the MTP to a single area is due to the anatomical proximity of these different nervous entry points, thus resulting in somewhat overlapping electromyographic identification. Therefore, if there is one MTP3 and one MTP5 that are clinically relevant, we can state that these MTP correspond to two and three motor plates, respectively. Our hypothesis was that MTP could be related to muscle innervation; therefore, this anatomical study was based on the dissection of adult cadavers to observe where branches of the spinal accessory nerve entered the muscle belly and whether there was a positive correlation with MTP. As for the trapezius muscle, two additional MTP corresponding to its tendinous insertion can also be responsible for painful disorders, although there is no relation to the end motor plates. MTP 4 and 6 were also observed in our studies, and no anatomical variation was detected. MTP4 was found on the medial aspect of the spine of the scapula and MTP6 on the acromion, both of which are sites of tendinous insertion of the trapezius muscle (Fig. 1).

We believe that knowledge of the anatomical basis of MTP is a cornerstone that will help provide a precise map for clinical applications related to certain painful disorders and that further investigation of trigger points in other muscles is needed. 
AKAMATSU, F. E.; SALEH, S.; PINESI, H. T.; RODRIGUES, K. R.; ZANDONÁ, C. B.; ANDRADE, M. \& JACOMO, A. L.Bases anatómicas de los puntos de gatillo miofasciales del músculo trapecio. Int. J. Morphol., 31(3):915-920, 2013.

RESUMEN: El objetivo de este estudio fue correlacionar los sitios de entrada de los ramos del nervio accesorio en el músculo trapecio con placas motoras y los puntos de gatillo miofasciales. A pesar de las correlaciones anatomoclínicas se constituyeren en la principal característica de los puntos de gatillo, no hay informes en la literatura describiendo sobre la distribución de los ramos del nervio accesorio y su relación anatómica con los puntos de gatillo. Ambos músculos trapecio de doce cadáveres adultos fueron disecados por los autores (profesores de anatomía y estudiantes de postgrado en Medicina) para observar el punto exacto donde los ramos del nervio accesorio espinal penetraban en el vientre muscular. La disección se llevó a cabo respetando las capas estratigráficas para preservar la inervación del músculo ubicada profundamente a éste. Ocho puntos fueron identificados: En todos los casos correspondieron a la descripción clínica de los puntos gatillo miofasciales y eran comunes a todos los cadáveres. Esta correlación anatomoclínica entre la ramificación del nervio espinal accesorio y los puntos de gatillo miofascial es útil para una mejor comprensión de la fisiopatología de los puntos gatillo y puede proporcionar una base para un abordaje diagnóstico y terapéutico racional para estos trastornos.

PALABRAS CLAVE: Puntos gatillo; Músculo trapecio; Anatomía; Nervio; Miofascial.

\section{REFERENCES}

Basmajian, J. V. \& De Luca, C. J. Muscles Alive: Their Functions Revealed by Electromyography. $5^{\text {th }}$ ed. Baltimore, Lippincott Williams \& Wilkins, 1985.

Chen, K. H.; Hong, C. Z.; Kuo, F. C.; Hsu, H. C. \& Hsieh, Y. L. Electrophysiologic effects of a therapeutic laser on myofascial trigger spots of rabbit skeletal muscles. Am. J. Phys. Med. Rehabil., 87(12):1006-14, 2008.

Chu, J. Dry needling (intramuscular stimulation) in myofascial pain related to lumbosacral radiculopathy. Eur. J. Phys. Med. Rehabil., 5(4):106-21, 1995.

Fernández-de-las-Peñas, C.; Ge, H. Y.; Alonso-Blanco, C.; González-Iglesias, J. \& Arendt-Nielsen, L. Referred pain areas of active myofascial trigger points in head, neck, and shoulder muscles, in chronic tension type headache. J. Bodyw. Mov. Ther., 14(4):391-6, 2010.

Fumal, A. \& Schoenen, J. Tension-type headache: current research and clinical management. Lancet Neurol., 7(1):70-83, 2008.

Ge, H. Y.; Fernandez-de-las-Penas, C.; Madeleine, P. \& ArendtNielsen, L. Topographical mapping and mechanical pain sensitivity of myofascial trigger points in the infraspinatus muscle. Eur. J. Pain., 12(7):859-65, 2008.

Ge, H. Y.; Nie, H.; Madeleine, P.; Danneskiold-Samsøe, B.; Graven-Nielsen, T. \& Arendt-Nielsen, L. Contribution of the local and referred pain from active myofascial trigger points in fibromyalgia syndrome. Pain, 147(1-3):233-40, 2009.

Harden, R. N.; Bruehl, S. P.; Gass, S.; Niemiec, C. \& Barbick, B. Signs and Symptoms of the Myofascial Pain Syndrome: A National Survey of Pain Management Providers. Clin. J. Pain., 16(1):64-72, 2000.

Hong, C. Z. \& Hsueh, T. C. Difference in pain relief after trigger point injections in myofascial pain patients with and without fibromyalgia. Arch. Phys. Med. Rehabil., 77(11):1161-6, 1996.

Hong, C. Z. Myofascial trigger points: pathophysiology and correlation with acupuncture points. Acupunct. Med., 18(1):417, 2000.

Hsueh, T. C.; Cheng, P. T.; Kuan, T. S. \& Hong, C. Z. The immediate effectiveness of electrical nerve stimulation and electrical muscle stimulation on myofascial trigger points. Am. J. Phys. Med. Rehabil., 76(6):471-6, 1997.

Huguenin, L. K. Myofascial trigger points: the current evidence. Phys. Ther. Sport, 5:2-12, 2004.

Karakurum, B.; Karaalin, O.; Coskun, O.; Dora, B.; Uçler. S. \& Inan, L. The 'dry- needle technique': intramuscular stimulation in tension-type headache. Cephalalgia, 21(8):813-7, 2001.

Lavelle, E. D.; Lavelle, W. \& Smith, H. S. Myofascial Trigger Points. Anesthesiol. Clin., 25(4):841-51, 2007.

Merskey, H. \& Bogduk, N. Classification of chronic pain: descriptions of chronic pain syndromes and definitions of pain terms. ${ }^{\text {2nd }}$ ed. Seattle, IASP Press, 1994.

Moore, K. L. \& Dalley, A. F. Clinically Oriented Anatomy. $6^{\text {th }}$ ed. Baltimore, Lippincott Williams \& Wilkins, 2010.

Olavi, A.; Pekka, R.; Pertti, K. \& Pekka, P. Effects of the infrared laser therapy at treated and non-treated trigger points. Acupunct. Electrother. Res., 14(1):9-14, 1989.

Sciotti, V. M.; Mittak, V. L.; DiMarco. L.; Ford, L. M.; Plezbert, J.; Santipadri, E.; Wigglesworth, J. \& Ball, K. Clinical precision of myofascial trigger point location in the trapezius muscle. Pain, 93(3):259-66, 2001.

Simons, D. G.; Travell, J. G. \& Simons, L. S. Myofascial Pain and 
AKAMATSU, F. E.; SALEH, S.; PINESI, H. T.; RODRIGUES, K. R.; ZANDONÁ, C. B.; ANDRADE, M. \& JACOMO, A. L. Anatomical basis of the myofascial trigger points of the trapezius muscle. Int. J. Morphol., 31(3):915-920, 2013.

Dysfunction: The Trigger Point Manual. $2^{\text {nd }}$ ed. Baltimore, Lippincott Williams \& Wilkins, 1999.

Simons, D. G. Do endplate noise and spikes arise from normal motor endplates? Am. J. Phys. Med. Rehabil., 80(2):134-40, 2001.

Simons, D. G.; Hong, C. Z. \& Simons, L. S. Endplate potentials are common to midfiber myofacial trigger points. Am. J. Phys. Med. Rehabil., 81(3):212-22, 2002.

Simons, D. G; Travell, J. G. \& Simons, L. S. Myofascial Pain and Dysfunction: The Trigger Point Manual. Baltimore, Lippincott Williams \& Wilkins, 2005.

Stranding, S. Gray's Anatomy. $40^{\text {th }}$ ed. London, Churchill Livingstone, 2008.

Tollison, C. D.; Satterthwaite, C. D. \& Tollison, J. Handbook of Pain Management. $2^{\text {nd }}$ ed. Baltimore, Lippincott Williams \& Wilkins, 2002.

Gran, J. T. The epidemiology of chronic generalized musculoskeletal pain. Best Pract. Res. Clin. Rheumatol., 17(4):547-61, 2003.

White, K. P. \& Harth, M. Classification, epidemiology and natural history of fibromyalgia. Curr. Pain Headache Rep., 5(4):3209, 2001.
Correspondence to:

Flávia Emi Akamatsu

Rua Alexandre Dumas 1410, ap. 154

Chácara Santo Antonio

Santo Amaro

CEP:04717003

São Paulo

BRAZIL

Phone: 551130618277

Email: flaea@usp.br

Received: 22-11-2012

Accepted: 03-02-2013 